\title{
The production of fatty acid modifying enzyme (FAME) and lipase by various staphylococcal species
}

\author{
J. P. LONG, J. HART, W. ALBERS and F. A. KAPRAL
}

Department of Medical Microbiology and Immunology, The Ohio State University, Columbus, OH 43210, USA

\begin{abstract}
Summary. Eighty-six strains encompassing 11 species of coagulase-negative staphylococci were examined for the production of fatty acid modifying enzyme (FAME) and lipase. Staphylococcus schleiferi and S. saprophyticus most closely resembled $S$. aureus in that $80 \%$ of the strains produced both enzymes. In contrast, no strains of $S$. lugdunensis and $S$. haemolyticus tested produced these enzymes. S. simulans was unusual in that eight of 10 strains produced FAME, but only one produced lipase. Among the other species the proportion of strains producing both enzymes ranged from 10 to $60 \%$. Generally there was a strong correlation between FAME and lipase production.
\end{abstract}

\section{Introduction}

The multiplication and survival of Staphylococcus aureus within abscesses is controlled by the host through the production of two kinds of bactericidal lipids. ${ }^{1-3}$ Most strains of $S$. aureus produce an esterifying enzyme (fatty acid modifying enzyme; FAME) which can inactivate these bactericidal lipids and this enzyme appears to be important for the organism's survival in host tissues., ${ }^{4,5}$ FAME is inhibited by glycerides, and the host delivers large amounts of triglycerides into the core of abscesses which keeps this enzyme non-functional. ${ }^{2,6}$ However, if the organism can also elaborate lipase, this enzyme can relieve the inhibition. Therefore, to effectively negate the bactericidal activity of the lipids in lesions, the organism must be able to produce both FAME and lipase.

Currently, there are $c .28$ known species of staphylococci other than $S$. aureus. Collectively, these are called coagulase-negative staphylococci (CNS), even though a few do produce coagulase, or clumping factor. Whereas it has been known for some time that some of these organisms can elaborate lipase, ${ }^{7.8}$ the production of FAME has not been evaluated.

\section{Materials and methods}

\section{Staphylococcal cultures}

Cultures of $S$. epidermidis, S. haemolyticus, $S$. warneri, S. lugdunensis, S. saprophyticus, S. simulans, $S$. schleiferi, S. caprae, $S$. hominis, $S$. cohnii and $S$. capitis were obtained either from Dr J. Fluerette at the

Received 3 July 1991; revised version accepted 23 Dec. 1991.
National Staphylococcal Reference Center in Lyon, France, or from Dr L. Ayers at the University Hospital of The Ohio State University. Most strains had been isolated from closed-space lesions.

\section{Evaluation of FAME production}

Each strain was grown in $100-\mathrm{ml}$ volumes of trypticase soy broth and was incubated at $37^{\circ} \mathrm{C}$ for $24 \mathrm{~h}$ with agitation. The culture supernates were divided into several portions and were kept frozen at $-20^{\circ} \mathrm{C}$ until required.

For these studies, a simpler FAME assay was developed which measured the esterification of oleic acid to butanol and which quantified the ester by gas chromatography. ${ }^{4,5} \mathrm{~A}$ solution of oleic acid in HPLCgrade butanol $(4 \mathrm{mg} / \mathrm{ml})$ was prepared; $50 \mu \mathrm{l}$ of this solution was placed in a lipid-clean glass screw-capped vial and to this was added $700 \mu \mathrm{l}$ of $0.1 \mathrm{M}$ sodium phosphate buffer ( $\mathrm{pH} \mathrm{6.0)}$ and $250 \mu$ lof culture supernate. The mixture was incubated for $20 \mathrm{~min}$ in a water bath at $37^{\circ} \mathrm{C}$ with constant shaking. Each sample was extracted twice with 2-ml volumes of ethyl ether:methanol $(6: 1 \mathrm{v}: \mathrm{v})$ and once with $2 \mathrm{ml}$ of ethyl ether. The ether phases were pooled and dried under nitrogen. The extracted lipids were dissolved in $40 \mu \mathrm{l}$ of hexane and $1-\mu l$ samples were injected into a gas chromatograph fitted with a 30-m carbowax $20 \mathrm{M}$ capillary column (Ohio Valley, Marietta, OH, USA). Using helium as the carrier gas, the butyl ester eluted at $4.4 \mathrm{~min}$ and the free oleic acid at $13.0 \mathrm{~min}$. The areas under the peaks were integrated and the percentages of free oleic acid and butyl ester were calculated. Culture supernates negative for FAME activity were re-tested to verify lack of enzyme production by the same procedure, except that the reaction mixture was incubated for $2 \mathrm{~h}$ instead of $20 \mathrm{~min}$. 
One unit of FAME activity (butanol unit) was defined as the esterification of $10 \mathrm{nmol}$ of oleic acid/min. Under the test conditions, this was equivalent to $28 \%$ esterification of the oleic acid during the 20 min incubation period.

\section{Evaluation of lipase activity}

A substrate suspension, similar to that used by Brunner and co-workers, ${ }^{9}$ was prepared by homogenising $2 \mathrm{ml}$ of sodium taurocholate $(15 \mathrm{mg} / \mathrm{ml})$ with $5 \mathrm{ml}$ of gum acacia $10 \%$ and $15 \mathrm{mg}$ of triolein. To this was added $2 \mathrm{ml}$ of $3 \mathrm{M} \mathrm{NaCl}, 1 \mathrm{ml}$ of $0.075 \mathrm{M} \mathrm{CaCl}_{2}$, and $4 \mathrm{ml}$ of distilled $\mathrm{H}_{2} \mathrm{O}$. The mixture was adjusted to $\mathrm{pH} 8.0$ while stirring and the final volume was adjusted to $15 \mathrm{ml}$ with water.

To evaluate lipase production, $4 \mathrm{ml}$ of culture supernate was added to $1 \mathrm{ml}$ of substrate. The $\mathrm{pH}$ was again adjusted to 8.0 and the mixture was incubated in a water bath for $18 \mathrm{~h}$ at $37^{\circ} \mathrm{C}$ with constant agitation. After incubation, the lipids were extracted by the method of Bligh and Dyer ${ }^{10}$ and dried under nitrogen.

The dried sample was dissolved in $240 \mu$ l of hexane and $20 \mu \mathrm{l}$ of this was spotted on silica gel G-coated plates. The plates were developed in hexane:ethyl ether:acetic acid $(80: 20: 1)$ and dried. Lipids were visualised by spraying with sulphuric acid:dichromate and charring at $180^{\circ} \mathrm{C}$ for $1 \mathrm{~h}$. Lipid extracts of uninoculated medium with substrate as well as samples of pure triolein and oleic acid were included as controls. The procedure can detect the release of as little as $0.6 \%$ of the fatty acid in the substrate.

\section{Bactericidal activity}

The method for determining the sensitivity of a strain to the bactericidal lipids has been described in detail. ${ }^{1}$ In this study, oleic acid was used as a representative lipid because it is the predominant fatty acid in the free fatty acid pool produced in abscesses.

\section{Results}

Between five and 10 strains from each of 11 staphylococcal species were examined for FAME and lipase production (table I). Of these, S. schleiferi most closely resembled $S$. aureus ${ }^{5}$ in that $80 \%$ of the strains were strong producers of both FAME and lipase. Five of six $S$. cohnii strains and seven of nine $S$. saprophyticus strains also produced both enzymes. In contrast, no strains of $S$. lugdunensis and $S$. haemolyticus tested produced FAME or lipase. S. simulans was unusual in that, whereas eight of 10 strains were strong FAME producers, only one of these strains could elaborate lipase. Among the other strains, enzyme production was less consistent.

Although only 19 strains were tested for sensitivity to oleic acid, most were found to be sensitive (table II)
Table I. FAME (F) and lipase (L) production among coagulase-negative staphylococci

\begin{tabular}{|c|c|c|c|c|c|}
\hline \multirow{2}{*}{ Species } & \multirow{2}{*}{$\begin{array}{c}\text { Number of } \\
\text { strains } \\
\text { tested }\end{array}$} & \multicolumn{4}{|c|}{$\begin{array}{l}\text { Number of strains of } \\
\text { each species that were }\end{array}$} \\
\hline & & $\mathbf{F}^{+} \mathbf{L}^{+}$ & $\mathrm{F}^{+} \mathrm{L}^{-}$ & $\mathbf{F}^{-} \mathbf{L}^{+}$ & $\mathbf{F}^{-} \mathbf{L}^{-}$ \\
\hline S. epidermidis & 9 & 3 & 1 & 2 & 3 \\
\hline S. saprophyticus & 9 & 7 & 0 & 2 & 0 \\
\hline S. simulans & 10 & 1 & 7 & 0 & 2 \\
\hline S. lugdunensis & 10 & 0 & 0 & 0 & 10 \\
\hline S. haemolyticus & 9 & 0 & 0 & 0 & 9 \\
\hline S. warneri & 5 & 3 & 0 & 0 & 2 \\
\hline S. schleiferi & 10 & 8 & 0 & 2 & 0 \\
\hline S. caprae & 6 & 2 & 2 & 0 & 2 \\
\hline S. hominis & 6 & 3 & $\theta$ & 0 & 3 \\
\hline S. cohnii & 6 & 5 & 0 & 0 & 1 \\
\hline S. capitis & 6 & 1 & 3 & 0 & 2 \\
\hline
\end{tabular}

Table II. Sensitivity of selected coagulase-negative staphylococci to oleic acid

\begin{tabular}{llc}
\hline Species & $\begin{array}{c}\text { Production of FAME (F) } \\
\text { and lipase (L) }\end{array}$ & $\begin{array}{c}\text { Oleic acid } \\
\text { LD50/mg }\end{array}$ \\
\hline S. schleiferi & $\mathrm{F}^{+} / \mathrm{L}^{-}$ & 760 \\
S. haemolyticus & $\mathrm{F}^{-} / \mathrm{L}^{-}$ & 310 \\
S. saprophyticus & $\mathrm{F}^{-} / \mathrm{L}^{-}$ & 2250 \\
& $\mathrm{~F}^{-} / \mathrm{L}^{-}$ & 1250 \\
S. simulans & $\mathrm{F}^{+} / \mathrm{L}^{+}$ & 910 \\
& $\mathrm{~F}^{-} / \mathrm{L}^{+}$ & 4500 \\
S. cohnii & $\mathrm{F}^{+} / \mathrm{L}^{+}$ & 81 \\
& $\mathrm{~F}^{+} / \mathrm{L}^{-}$ & 1850 \\
S. caprae & $\mathrm{F}^{+} / \mathrm{L}^{+}$ & $<40$ \\
& $\mathrm{~F}^{+} / \mathrm{L}^{+}$ & 1000 \\
S. hominis & $\mathrm{F}^{+} / \mathrm{L}^{+}$ & 3100 \\
& $\mathrm{~F}^{+} / \mathrm{L}^{+}$ & 2200 \\
S. warneri & $\mathrm{F}^{-} / \mathrm{L}^{-}$ & 9400 \\
S. lugdunensis & $\mathrm{F}^{+} / \mathrm{L}^{+}$ & 1550 \\
& $\mathrm{~F}^{+} / \mathrm{L}^{+}$ & 220 \\
S. capitis & $\mathrm{F}^{+} / \mathrm{L}^{+}$ & 470 \\
& $\mathrm{~F}^{-} / \mathrm{L}^{-}$ & 8500 \\
& $\mathrm{~F}^{-} / \mathrm{L}^{-}$ & 1050 \\
& $\mathrm{~F}^{+} / \mathrm{L}^{+}$ & \\
& & 9500 \\
& &
\end{tabular}

and a few, such as the two $S$. lugdunensis strains, were inordinately sensitive to the fatty acid.

\section{Discussion}

Although the system of bactericidal lipids plays an important role in controlling the growth and survival of $S$. aureus in focal lesions, it is not known whether this host defence mechanism is brought to bear on other species of staphylococci. ${ }^{1,2}$ In the case of $S$. aureus, two enzymes assist the organism in circumventing these lipids. The first is FAME, an esterifying 
enzyme that can inactivate both the free fatty acid pool and the monoglycerides. ${ }^{3-5}$ However, FAME is strongly inhibited by triglycerides and the host consigns large amounts of triglycerides to the lesion. The second enzyme, lipase, can relieve this inhibition and can also degrade the bactericidal monoglyceride directly. Therefore, to obtain the greatest benefit, the organism should produce both enzymes simultaneously. Whereas about $99.5 \%$ of $S$. aureus strains produce lipase, ${ }^{7}$ only $80 \%$ produce FAME, ${ }^{5}$ yet it is only these strains that are able to invade the tissues. ${ }^{4}$

In the present study, $c .80 \%$ of $S$. schleiferi, $S$. cohnii, and $S$. saprophyticus strains produced both FAME and lipase, but none of the $S$. haemolyticus and $S$. lugdunensis strains produced either enzyme. Among the other species, the proportion of strains producing both enzymes ranged from 10 to $60 \%$.

Generally, there appeared to be a strong correlation between FAME and lipase production (table I). Of a total of 86 strains examined, $33(38 \%)$ produced both enzymes, and $35(41 \%)$ produced neither. Only 18 strains $(21 \%)$ produced one enzyme but not the other $\left(\chi^{2}\right.$ analysis: $\left.p<0.001\right)$. This kind of relationship might be expected if the host utilised the defence mechanism against certain species, but not against others. Since production of a single enzyme would be of little value to a strain in negating the effect of bactericidal lipids, selective pressures would favour strains producing both enzymes in those cases where the defence mechanism was being utilised, but no such pressures would come into play in instances where the mechanism was not employed.

Of the 19 strains evaluated for their sensitivity to oleic acid (table II), 11 strains produced both FAME and lipase. The average level of sensitivity to the fatty acid for this group was $1030 \mathrm{LD} 50 / \mathrm{mg}$ (median, $910 \mathrm{LD} 50 / \mathrm{mg}$ ). In contrast, six strains produced neither enzyme and in this group the average level of sensitivity was much greater, $5200 \mathrm{LD} 50 / \mathrm{mg}$ (median, $5375 \mathrm{LD} 50 / \mathrm{mg}$ )

Although our findings are compatible with the concept that at least some species of CNS may produce FAME and lipase for defensive purposes, further studies are obviously necessary to determine the validity of this view. Many infections due to CNS are associated with the presence of various types of foreign bodies, particularly those made of certain plastics. In addition to determining whether the host utilises, or attempts to utilise, the system of bactericidal lipids in response to infection with $\mathrm{CNS}$, the effect of plastics on the mobilisation process or on the efficacy of the lipids must also be considered.

This investigation was supported by Public Health Service grant AI-19879 from the National Institute of Allergy and Infectious Disease.

\section{References}

1. Dye ES, Kapral FA. Survival of Staphylococcus aureus in intraperitoneal abscesses. J Med Microbiol 1981; 14: 185-194.

2. Dye ES, Kapral FA. Characterization of a bactericidal lipid developing within staphylococcal abscesses. Infect Immun 1981; 32: 98-104.

3. Engler HD, Kapral FA. The production of a bactericidal monoglyceride in staphylococcal abscesses. $J$ Med Microbiol 1992; 37: 232-234.

4. Mortensen JE, Shryock TR, Kapral FA. Modification of bactericidal fatty acids by an enzyme of Staphylococcus aureus. J Med Microbiol 1992; 36: 293-298.

5. Kapral FA, Smith S, Lal D. The esterification of fatty acids by Staphylococcus aureus fatty acid modifying enzyme

(FAME) and its inhibition by glycerides. $J$ Med Microbiol 1992; 37: 235-237.

6. Shryock TR, Dye ES, Kapral FA. The accumulation of bactericidal lipids in staphylococcal abscesses. $J$ Med Microbiol 1992; 36: 332-336.

7. Elek SD. Staphylococcus pyogenes. London, Livingstone. 1959: 290-292.

8. Cohen JO. The staphylococci. New York, Wiley-Interscience. 1972: 227.

9. Brunner H, Gemmell CG, Huser H, Fehrenbach FJ. Chemical and biological properties of Staphylococcus aureus lipase. In: Jeljaszewicz J (ed) Staphylococci and staphylococcal infections. Zentralbl Bakteriol; Suppl 10. Stuttgart, Gustave Fischer Verlag. 1981: 329-333.

10. Bligh EG, Dyer WJ. A rapid method of total lipid extraction and purification. Can J Biochem Physiol 1959; 37: 911-917. 